\title{
Designing Household Scale Water Filtering with Two Tubes
}

\author{
Sugiyanto", Miftahudin Yudiansyah, Rizky Anggit Maya Olif Fatul Khasanah \\ Faculty of Science and Technology, UIN Sunan Kalijaga \\ Jl Marsda Adisucipto No 1 Yogyakarta 55281, Yogyakarta, Indonesia.Telp. +62-274-540971, Fax. +62-274-519739 \\ Email: sugimath@yahoo.co.id
}

\begin{abstract}
The basic concept of water treatment by filtering is to separate solids or colloids from water using a filter. In the screening process there are two types, namely physics and biology. The particles in the turbid water will be physically retained by the sand layer in the filter. On the other hand, pathogenic bacteria that are retained by the filter will be destroyed by the filter installed. The design process in this paper is a simple process that can be assembled by a small family and the price is quite cheap.
\end{abstract}

Keywords: Water, Filtering

\section{INTRODUCTION}

Water is the main element of life. Water is the most needed substance for human life [1]. The water in question is fresh water or clean water which will be directly used in life [1], [2]. Clean water limits are water that can be used by humans for their daily needs that meet health requirements and can be drunk when cooked [1], [2], [3]. Clean water can come from rainwater, surface water, groundwater and spring water [4].

Humans and all living things need water [5]. Water is a material that makes life happen on earth [6], [5]. According to doctors and human health experts must drink 8 glasses of water per day [6]. Plants and animals also need water. So that it can be said that water is one source of life [6], [7]. All living organisms are composed of cells that contain at least $60 \%$ water and their metabolic activity takes place in aqueous solutions [7].

Processing of water used for drinking water can be done by simple processing or with complete processing [7]. The higher the water pollution so that more water treatment techniques are carried out to treat water so that it can be used for drinking water [7], [8]. One of the drinking water treatment systems is filtration. Filtration is needed to improve the level of contaminants such as bacteria, color, taste, odor, hardness, iron, so that clean water can be obtained that meets drinking water quality standards [8].

This household-scale water filter is needed for areas where the well water is not good, such as Sewon District, Bantul Regency, Yogyakarta Special Region. This is because, river water from Mount Merapi, through the City of Yogyakarta, there is the disposal of wastes, both household waste and factory waste. Making this household scale water filtering is quite simple so that every small family can buy it.

\section{MATERIALS AND METHODS}

In making this household scale water filtering the material used is 2 pcs Nanotec Housing, 2 pcs Bracket Housing, 1 pcs DN 3/4 ", 2 pcs SDL 3/4", 1 pcs Sediment Filter, 1 pcs Carbon CTO, 2 Sets Screws, 1 pcs seal tape, 1 pcs PVC glue, while the tool is 2 pcs Wrench Housing. How to install these materials is quite simple, namely in Figure 1.

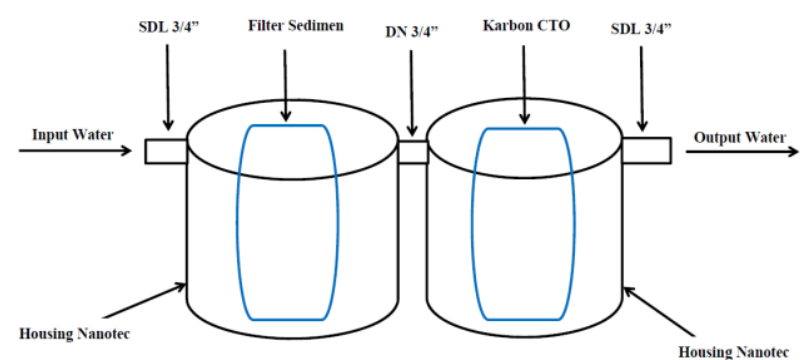

Figure 1. House hold scale water filtering with two tubes.

Based on Minister of Health Regulation No. 492 of 2010 [9] concerning drinking water quality and Government Regulation No. 82 of 2001 [10] concerning the management of water quality and control of water pollution, stating that water that is suitable to be consumed and used daily is water that has good quality as drinking water and clean water sources (raw), including having to fulfill the requirements physical that is odorless, tasteless, not cloudy, as well as colorless, water $\mathrm{pH}=6.5-8.5$, and $\mathrm{Fe} \mathrm{mg} 0.3 \mathrm{mg} / 1$. Therefore, after being assembled, it is necessary to check from this tool, namely checking smell, taste, turbidity, color, $\mathrm{pH}$ of water and iron content.

\section{RESULTS AND DISCUSSION}

Based on the experiments that have been carried out and the method used, it was proved that this method 
can be used for water purification process. This method is very simple and does not require special tools. All tools used can be easily obtained. This method can be socialized to the community to overcome the needed of clean water in the community.

The quality of water produced from this filtration tool can be measured by chemical, physical and biological parameters. In terms of chemistry, the $\mathrm{pH}$, DO (dissolved oxygen), taste, and color of the water can be observed. Physically, the water quality can be seen from the odor, the amount of dissolved solids, turbidity, and temperature. In terms of biology, the content of gram negative bacteria which can be detrimental can be measured. As long as the level does not exceed the threshold value, then the filtered water can be consumed.

This method is very suitable to be applied to the wider community because the needs of clean water always increases along with the increase in population. This method is expected to be one of the solutions to needed of clean water in the community.

\section{CONCLUSIONS}

The design of a simple filter with two tubes is quite simple. It is expected that each family in the area where the river passes through this city is installed. The next step requires measurement of odor, taste, turbidity, color, water $\mathrm{pH}$ and iron content.

\section{REFERENCES}

D. Michael, La Grega, 2001, Hazardous Waste management, Mc. Graw Hill, New York.

Haryanto, 2010, Analisis Kualitas Air Semur Dengan Parameter Cl Dan CaCo3, Tugas Akhir Universitas Muhammadiyah Yogyakarta, Yogyakarta.

Keputusan Menteri Kesehatan Republik Indonesia Nomor 492/Menkes/SK/IV/2010 tentang Syarat-syarat dan Pengawasan Kualitas Air Minum.

M. Sobsey, 2002, Managing water in the home: accelerating health gains from improved water supply, World Health Organization, Geneva, Switzerland

Peraturan Pemerintah Republik Indonesia Nomor 82 Tahun 2001 tentang Pengelolaan Kualitas Air dan Pengendalian Pencemaran Air.

Prawiro, 2009, Dasar-Dasar Pengelolaan Air Limbah, Penerbit Universitas Indonesia, Jakarta.

R. K. Linsley, 1985, Teknik sumberdaya Air, Penerbit Airlangga, Jakarta.

R. L. Droste, 1997, Theory and Practice of water and Wastewater Treatment, Jhon Wiley \& Sons, Inc. New York.

R. Middleton, 2003, Prone Resources for Clean Water, American Water Works Assosiation, West Quincy Avenue, Denver, Colo, 80235, U.S.A.

Selintung dan Syahrir. 2012." Studi Pengolahan Air Melalui Media Filter Pasir Kuarsa (Studi Kasus Sungai Malimpung)”, Jurnal, Universitas Hasanuddin Makassar. 